\title{
Developing Competencies for Education for Sustainable Development: A Case Study of Canadian Faculties of Education
}

\author{
Laura Sims $^{1} \&$ Thomas Falkenberg ${ }^{2}$ \\ ${ }^{1}$ Faculty of Education, Université de Saint-Boniface, Winnipeg, Canada \\ ${ }^{2}$ Faculty of Education, University of Manitoba, Winnipeg, Canada \\ Correspondence: Laura Sims, Faculty of Education, Université de Saint Boniface, Winnipeg, MB, R2H 0H7, Canada. \\ Tel: 1-204-237-1818 ext 458. E-mail: 1sims@ustboniface.ca
}

Received: August 25, 2013

Accepted: September 6, 2013

Online Published: September 10, 2013

doi:10.5430/ijhe.v2n4p1

URL: http://dx.doi.org/10.5430/ijhe.v2n4p1

\begin{abstract}
Education is paramount when trying to enable a change in values and attitudes towards sustainability. Higher education in faculties of education plays an important role in working toward this change because of its impact on future and practicing teachers in the school systems. This study inquires into the current role of education for sustainable development (ESD) in undergraduate and graduate teacher education programs at Canadian universities, with a particular focus on promising practices and initiatives toward a reorientation of teacher education for sustainability. A qualitative case study approach was used identifying promising initiatives as well as challenges and enablers of reorienting teacher education toward sustainability at four Canadian universities. The discussion of results is framed by how identified initiatives relate to the development of core ESD competences for educators as established by UNECE (2012). The results of the study suggest the importance of experiential, inter-disciplinary and inter-institutional learning, of problem-based learning around real-life issues with community and the natural environment, and of building partnerships with colleagues, students, and community organizations.
\end{abstract}

Keywords: Education for sustainability, Faculties of education, Teacher competences, ESD in higher education

\section{Introduction}

\subsection{Education for Sustainable Development (ESD)}

Sustainable development is concerned with the creation and the sustaining of the conditions for current and future generations of humans to live well on this planet. The notion of sustainable development was introduced by Brown (1981) and then adopted by the UN's World Commission on Environment and Development: "Sustainable development is development that meets the needs of the present without compromising the ability of future generations to meet their own needs" (WCED, 1987, p. 43). Hence, right from the beginning a multi-prong approach to the idea of a sustainable society was taken that went beyond concerns for only the destruction of the natural environment and included the concern for the meeting of the essential needs of all people and that those needs are met in a sustainable way in consideration of the needs of future generations, including concern for equitable access to, and distribution of, resources (e.g., The Earth Charter, n.d.; Jucker, 2002), a link that is particularly brought into focus in a critical pedagogy of place (e.g., Greenwood, 2008; Gruenewald, 2003; Stevenson, 2008). Although not all scholars share the multi-prong approach to sustainable development (e.g., Scott \& Gough, 2003, p. xiv), many scholars take a holistic, system-theoretical view of the way in which those prongs of sustainable development are interlinked (e.g., Capra, 2002; Clayton and Radcliffe, 1996; Senge et al., 2008). In 2005 Summers, Childs, and Corney "identify in the literature a growing consensus that sustainable development must be conceptualised at the very least in terms of three dimensions: environment, economic and social" (p. 629).

The report by WCED (1987) recognized that "sustainable development requires changes in values and attitudes towards environment and development" (p. 111) and that education has to play a central role in achieving those changes in values and attitudes. Educational research has studied education as "a critical tool in the transformation towards sustainability" (Firth \& Winter, 2007, p. 600) in the K-12 school system (e.g., Robertson \& Krugly-Smolska, 1997; Summers et al., 2003), the tertiary system (e.g., Mochizuki \& Fadeeva, 2010; Minguet, Martinez-Agut, Palacios, Piňero, \& Ull, 2011), and in informal / non-formal education settings (e.g., Wheeler, 2007; Mahruf et al., 
2011). The research identified three domains of the educational process relevant for such transformation: first, the content of what is being taught (curriculum: for the tertiary level see, e.g., Blewitt \& Cullingford, 2004, and for the K-12 school system see, e.g., Hopkins, Damlamian, \& López Ospina, 1996; Paige et al., 2008; Robertson \& Krugly-Smolska, 1997); second, the pedagogy, with some scholars suggesting that sustainability education requires a constructivist approach to teaching (e.g., Firth \& Winter, 2007), an ecopedagogy that "overcomes the anthropocentrism of traditional pedagogies" (Gadotti, 2010, p. 205), and even a complete new paradigm of teaching to account for a holistic perspective on education for sustainability (e.g., Sterling, 2001); and third, the education and professional development of those who are ultimately the ones responsible for implementing ESD, the teachers. The study presented in this article focuses on the third domain: the education and professional development of teachers in faculties of education.

\subsection{The Problem: Reorienting Teacher Education Toward Sustainability}

In 1998 the United Nations Educational, Scientific and Cultural Organization (UNESCO) initiated work on reorienting teacher education toward sustainability, which led to the formation of an International Network of Teacher Education Institutions (McKeown \& Hopkins, 2007), a series of monographs on integrating ESD into teacher education programs (e.g., Hopkins et al., 2007; Hopkins \& McKeown, 2005; McKeown, 2006; Tilbury, 2011), a list of relevant competencies for educators (UNECE, 2012), and even a completely mainstreamed teacher education curriculum (UNESCO, 2010). The reorientation of teacher education, which is sometimes called mainstreaming of education for sustainability in teacher education programs "refers to the incorporation of ESD philosophy, content and activities within an initial teacher education system to such an extent that ESD becomes embedded within all policies and practices" (Ferreira et al., 2007, p. 226). Despite the work by UNESCO, the Network and others, we are not aware of any studies that report such mainstreaming for a teacher education program in any country. Quite to the contrary, Nolet (2009), for instance, writes that "today, sustainability education is almost nonexistent in the teacher education curriculum in the United States" (p. 430; see also Nolet, 2013, p. 54, for a similar assessment); Ferreira et al. (2007, p. 227) report a similar situation for Australian teacher education programmes. Despite the lack of mainstreaming, there are studies documenting the integration of ESD into teacher education programs around the world to various degrees (see, for instance, Alsop et al., 2007; Down, 2006; Ferreira et al., 2007; Fien \& Maclean, 2000; Firth \& Winter, 2007; McKeown \& Hopkins, 2007).

Based on reports by members of the International Network of Teacher Education Institutions, Hopkins and McKeown (2005, p. 30) have identified four classes of challenges to the reorienting of teacher education toward ESD (for some systematic empirical support of the list, see Down, 2006; Falkenberg \& Babiuk, in press; and Firth \& Winter, 2007). These four classes of challenges are:

- lack of awareness, support, and resources at the teacher education institutional level;

- lack of prioritizing sustainability in the educational community;

- the common orientation when reforming education systems and structures (which does not give consideration to education for sustainability and is generally undertaken within the traditional disciplinary curriculum frameworks, which makes the incorporation of the transdisiplinary education for sustainability a challenge);

- lack of establishing and sustaining partnerships (lack of partnerships with communities in which education for sustainability is taking place and lack of coordinated efforts between different branches of governments beside ministries of education).

\subsection{The Focus of the Study: Reorienting Teaching Education for Sustainability in Canada}

In Canada education, including post-secondary education, is under provincial jurisdiction. Teacher education programs that prepare for certification to the K-12 teaching profession are offered as undergraduate programs. Graduate programs (Master's and Ph.D. programs) are offered to practicing teachers as systematic professional development. The focus of this study is to inquire into the current role of ESD in undergraduate and graduate teacher education programs in Canadian universities.

Currently there is very little known about this role. What exists seems to fall into two types of research. First, there are studies on particular initiatives around the teaching of particular courses by individual course instructors (see, for instance, Alsop, Dippo, \& Zandvliet, 2007; Dippo, 2013). The second type are baseline-type studies, two of which we are aware of. There is a baseline study using in-depth interviews on the status of education for sustainability in the preparation of teachers in faculties of education in Manitoba, one of the ten provinces of Canada (Falkenberg \& Babiuk, in press), and there is a baseline study using survey and follow-up interviews on the status of ESD in Canadian faculties of education (Swayze, Creech, Buckler, \& Alfaro, 2012). The study reported on in this article 
builds upon the baseline study by Swayze et al. (2012) by using in-depth interviews with selected faculty members from selected Canadian faculties of education in order to explore promising practices and initiatives toward a reorientation of teacher education for sustainability in undergraduate and graduate programs in selected Canadian faculties of education.

\section{Method}

\subsection{Case Study Approach}

The general focus of the study is to inquire into the current role of ESD in undergraduate and graduate teacher education programs at Canadian universities. The study has two specific research questions: (1) What are the course-designs, pedagogical approaches, and other ESD-related initiatives used in Canadian teacher education programs (undergraduate and graduate) to help school teachers develop competencies for ESD? (2) What are challenges and enablers faced by university instructors who intend to develop those competencies?

In order to address these research questions, the study explores multiple cases within a bounded system (Creswell, 2007, p. 73), where the bounded system here is the teacher education programs at Canadian universities. The design of the study is a single-case, multiple-units case study (Yin, 2009, p. 46) where the Canadian teacher education context is the single case of the world-wide teacher education context and the selected teacher education programs of the selected faculties of education in Canada are the different units of analysis within the single case. Because of the lack of understanding of the status of ESD in Canadian teacher education programs (see section 1.3), the study has the character of an exploratory case study (Yin, 2009, p. 46).

\subsection{Site Selection, Data Collection and Analysis}

The following purposeful sampling procedure was used to identify interviewees for the study. Based on initial findings from the study by Swayze et al. (2012), four faculties of education (the units of the case study) were identified as particularly noteworthy in their attempts to integrate ESD into different aspects of their undergraduate and/or graduate programs. Key faculty members in each of the four institutions were identified, who, in turn, identified other members of the respective faculty who as well contributed to such integration of ESD. In total 20 faculty members across all four faculties of education were interviewed using semi-structured in-depth interviews in person or by phone by Sims between April and September 2012. The guiding interview questions were designed to explore interviewees' response to the two research questions of the study. The interviews were transcribed verbatim for later analysis. The data analysis consisted of coding and interpretation processes (Coffey \& Atkinson, 1996; Creswell, 2007; Maxwell, 1996) using the two research questions as guides for these processes. Nvivo (Muhr, 1997) was used to select and code data segments, create memos, and build families of codes based on themes that emerged from the data. Member checking was used for feedback on the accuracy of data presentation. Relevant documents (referenced below) were reviewed.

\section{Results: The Case Study Sites}

In the presentation of the study results real names of participants are used unless otherwise stated, a practice approved by the research ethics board and the respective participants. Participants were from faculties of education from four different universities (the units of this case study). Two of them are located in Toronto, the largest city in Canada in the province of Ontario: the Ontario Institute for Studies in Education / University of Toronto, and York University. The other two universities were located in Vancouver in the province of British Columbia: the University of British Columbia and Simon Fraser University. The results are organized and reported by university.

\subsection{Ontario Institute for Studies in Education / University of Toronto (OISE/UT)}

OISE/UT has a long-standing focus on social justice and equity issues as well as a more recent one on environmental education. Particularly under the leadership of Dr. Hilary Inwood, initiatives to integrate sustainability and environmental education at the faculty of education (OISE) at the University of Toronto started in 2007. Over the years she, in close collaboration with other individuals and university groups, worked to realize their goals through what has become the Environmental \& Sustainability Education (ESE) Infusion Initiative (n.d.). This initiative

aims ... to support one of the tenets, Social and Ecological Responsibility, of OISE's new institutional vision. It provides a nexus for ESE-related groups at OISE . . . to share information, co-develop events and programs, and work towards a greater level of sustainability in all that OISE does. (Environmental \& Sustainability Education Infusion Initiative, n.d., p. 1)

\subsubsection{Awareness-Raising Initiatives}

OISE/UT implements a variety of creative initiatives that aim to reduce their impact on the environment and raise 
awareness amongst the students and staff who frequent OISE/UT. Examples of their activities include, but are not limited to, promoting awareness through their "Fatal light awareness program" to prevent migrating birds from hitting their campus high-rise building or motivating people to walk the stairs by installing art in the stairways. In 2012-2013, they installed four eco-art projects showcasing a variety of student-created pieces of art related to environmental and sustainability education (for more details: http://www.oise.utoronto.ca/ese/ESE_in_Practice/Eco-Art_Projects.html). In 2012-2013, OISE/UT created a community-learning garden to

support integrated learning about ESE in our graduate and teacher education program...The garden is found in six large concrete planters at the front of the OISE/UT building, each with its own theme related to the foundational concepts of OISE/UT's programs: Aboriginal Education, Equity and Inclusive Education, Holistic Education, Creativity in Education and Environmental and Sustainability Education. Our hope is that these gardens will become a symbolic and physical manifestation of collaborative learning around social and ecological learning across all of OISE/UT's programs, and act as demonstration sites to inspire our students to integrate nature-based learning into their own personal and professional lives. (http://www.oise.utoronto.ca/ese/OISE_Learning_Garden/index.html)

OISE/UT also created a website with resources for pre- and in-service teachers (the link: http://www.oise.utoronto.ca/ese/).

\subsubsection{Undergraduate Teaching}

The integration of sustainability and environmental perspectives into OISE/UT's undergraduate program is manifested in a number of ways:

- Environmental and sustainability learning goals are listed explicitly in the vision for the qualities with which students graduate from OISE/UT's undergraduate programs (OISE/UT, 2011).

- The cohort system used in undergraduate teacher education programs allows for theme-based learning groups. Within the courses offered in each particular cohort program, that theme is woven throughout all of the courses. OISE/UT offers a Global Citizenship and Sustainable Development secondary cohort and an elementary Social and Eco-justice cohort. At best, cohort instructors take a team approach, regularly discussing student progress and how best to integrate the theme across the disciplines. Ideally, students' practica complement the desired thematic focus allowing students to see best practices in action. However, in less-than-ideal conditions, there is little to no time for instructors to meet and high instructor turn-over makes consistent integration challenging.

- The offering of an electives course linked to sustainability / environmental education. Dr. Inwood makes an effort to provide some theory in her ESD elective but also builds bridges with the community by taking students on field trips, and by having local non-governmental organizations come to give seminars. For the 2013-2014 academic year this elective, along with 17 others, was cut as a cost-saving measure.

- With funding provided through the Teacher Education Program Assistant (TEPA) program at OISE/UT, a doctoral student with expertise in ESD has been hired to infuse environmental and sustainability education themes across the broader curriculum offered to B.Ed. students, for instance, through presentations on environmental and sustainability education in many methods courses. In 2010-2011, the doctoral student spoke to 750 students. In 2013, funding for this doctoral student was cut by half as a cost-saving measure.

- ESD has been integrated into some of the curriculum and instruction courses. Jane Forbes, an elementary science educator in the program, argues that instructors must look to infuse sustainability education concepts into their courses, not just have a one-day intervention. Forbes explains how "in science, we want a critical question that could guide what we look at throughout our six classes with students like: 'how can we promote sustainability and environmental responsibility amongst diverse learners?""

- For interested bachelor of education students, OISE/UT provides the opportunity to have their experience and knowledge in environmental and sustainability education formally recognized through a certificate in environmental leadership. There is no financial cost associated with pursuing this certificate. To earn the certificate, students must complete all three components: a formal learning component (which includes course work, mentorship, or internship learning opportunities); a co-curricular learning component (which includes attending environmental and sustainability education talks, workshops or field trips); and a service learning component (which includes volunteering or participating in a environmental and sustainability education initiative at OISE/UT). In 2012-2013, the pilot year for this initiative, 60 students earned the Environmental Leadership Certificate. The hope is to be able 
to open this certificate program to graduate students as well. (For more details see http://www.oise.utoronto.ca/ese/EE_Leadership_Certificate.html)

3.1.3 Graduate Teaching

- OISE/UT offers an Adult Education for Sustainability Certificate Program. The program is also open to the general public.

- Graduate students in the Master of Teaching Program attend a one-day conference on ESD as part of their program.

- A variety of graduate courses related to ESD are also on offer, including Adult Education for Sustainability; The Pedagogy of Food; Environmental Studies in Science, Math and Technology; and Environmental Health, Education and Policy Change.

OISE/UT offers a mini-research grants program "Inquiry into Practice". David Montemurro, lecturer and coordinator of the Critical Global Citizenship and Environmental Sustainability teacher education cohort at OISE/UT, explained:

For the past decade we've had an 'inquiry into practice'...They're mini-research grants to support school-university partnerships that are thematic so recently it was teaching global matter in local classrooms. Profs and teachers put in an idea around a question, and this time it was 'how are students making sense of global content into local context in the greater-Toronto-area classroom?'...That research money provides instructors the opportunity to do things other than just teaching - an inquiry project to think deeply about something and to work with schools.

\subsection{York University}

York's faculty of education ESD work builds upon a very strong focus on equity and social justice issues in teacher education (see Dr. Don Dippo's description in Hopkins \& McKeown, 2005, p. 42). According to Dr. Dippo, over the past 15 years, in order to better integrate a focus on the environment, elective courses have been offered in both the undergraduate and graduate programs. An effort has been made to integrate the three components of ESD into the overall teacher education program through a specific core course in the pre-service program. He suggests that one of York's particular strengths in the area of ESD lies in providing a joint graduate diploma with the faculty of environmental studies and close collaboration with Learning for a Sustainable Future (see http://www.lsf-lst.ca) and the UNESCO Chair on Reorienting Teacher Education to Address Sustainability.

\subsubsection{Undergraduate Teaching}

The integration of ESD into the undergraduate program in the faculty of education at York University is manifested in a number of ways:

- The program offers two electives related to ESD. Dr. Dippo teaches his ESD elective course on campus but outside the conventional classroom (in the outdoors), actively making the link between the environment where they learn and the students' future teaching practice. Examples include finding authentic places which would act as appropriate learning environments and teaching mock lessons from there. For instance, on a dull November day to commemorate Remembrance Day, a future teacher recited a poem by Wilfred Owen and then had his classmates "write letters from the trenches", in the drizzle, with dull pencils, crouching against a concrete wall.

- There are initiatives to infuse ESD across courses in the undergraduate program. Recently, a mandatory course in general teaching methods was replaced by a course called "Teaching and Learning for Inclusive Classrooms". Dippo described the course as follows:

That course was ostensibly about general teaching methods - just focussing on lesson and long-range planning, curriculum documents - but the people teaching it saw it as an empty shell. So about five years ago there was an effort to come up with a broad vision of a more coherent, compelling course. Those teaching it worked on revisions to the course for a year or two. One of our faculty members working on the course was a very committed environmental educator. So now, this course has an explicit social justice agenda and it's where climate change and environmental education are taken up. That was a pretty remarkable achievement where the course had to be redesigned and approved at all levels. In the pre-service curriculum it's a core required course. However in practice, that course is sometimes team taught but more often it's taught by an individual and the extent to which that person has knowledge in those areas, that's the extent to which EE/ESD gets taken up. But it's there, and that's significant. 


\subsubsection{Graduate Teaching}

- At York University, a joint graduate diploma in Environmental/Sustainability Education is offered through the Faculties of Education and Environmental Studies. Students must take courses from both faculties, a couple of courses are mandatory but the rest are electives. Dr. Dippo explained:

We've a fairly good mix of interested people some of whose lives are grounded in schools and others whose lives are grounded in the NGO community...For those who want to learn about environmental sustainability, I think the collaboration between the two faculties serves them well...I think that this jointly-offered graduate diploma enables the faculty of education students to work more closely with community activists and that has been a good thing.

\subsection{University of British Columbia}

With respect to the broader university context, UBC has a long history of being a "sustainability mecca", according to Dr. Mark Edwards. UBC's strategic plan "Place and Promise" led to the creation of the UBC Sustainability Initiative, which led to dedicated resources to support faculty, staff and students in their ESD work. More specifically, within the faculty of education, Indigenous scholarship is a strong area of expertise. These individuals, in collaboration with other faculty members, are helping define what ESD means at UBC's faculty of education. Further, UBC's faculty of education includes a diverse group of individual faculty members whose areas of expertise closely and innovatively link the environment with pedagogy and social justice. ESD work is highlighted in research, in graduate courses and in their teacher education program. Much work has been done through the creation of a common vision for the faculty, particularly through groups like the Environmental Education Caucus (see Environmental Education Caucus, 2011), and the creation of sustainability-focused graduate programs in the faculty of education. Some part of this work has been university-driven and other parts have been grassroots-driven, particular through student initiatives, according to Dr. Edwards.

\subsubsection{Undergraduate Teaching}

The integration of ESD into the undergraduate program in the faculty of education at UBC is manifested in a number of ways:

- UBC used to have a thematic cohort that integrated sustainable education and social justice in the two-year program for elementary teachers, but in the remaining one-year program (2013-14) that cohort is not offered anymore.

- UBC offers electives related to education for sustainability, including a long-standing outdoor education course.

- There are a number of initiatives of infusing ESD into different courses of the program. For instance, Dr. Susan Gerofsky, in collaboration with graduate students and colleagues from Land and Food Systems, has created a learning garden on UBC campus. She recognized that if learning through gardens in schools was to be supported, future teachers would need to learn to teach their subject areas (e.g., history, music, science, mathematics) in a garden through their university course-work. A learning garden can take many forms depending on the specific context: at UBC, after years of advocacy, Gerofsky and her team built the "Orchard Garden", which includes a small-scale version of a traditional Chinese market garden and reflects the historical relationship of Chinese-Canadian and Musqueam First Nation cultures. In 2011-12, over 500 pre-service teachers from various disciplines engaged with the garden as through outdoor learning experiences. Gerofsky said that to maintain a learning garden one needs to get a broad spectrum of people involved in the planning, construction and use of the garden (e.g. students, faculty, administration, planning and operations, community members). Accessing available grants is also important. The challenges that she has encountered in sustaining a learning garden have been: setting up an on-line commons (to share ideas) that is actually meaningful to users; engaging a broad and diverse community in garden activities; learning from and valuing different cultural approaches and gardening methods; and overcoming logistical challenges like organizing volunteers.

- There have been a number of initiatives to integrate ESD into undergraduate courses:

Dr. Gerofsky has conducted research linking math concepts with the natural environment. She uses the learning garden to provide opportunities for students to do math in a living environment. She explained:

In the winter we did workshops with student teachers on math and body measurements in the garden... We researched different ways that people have measured spaces and object with our bodies, using a pace, or a hand-span, or the width of a thumb to measure distances like a foot or an inch. We'd think about seed packets and how far apart particular seeds have to be 
planted...calculate how many packages of seeds were needed to seed a given garden bed. We used trigonometry to figure out how tall a certain tree was, and noticed where the shadow falls at different times of day...We thought about ideas like embedding shapes in the walls and pathways of the garden that embody mathematical ideas and puzzles like, for example, the 17th century Königsberg Bridge problem. This simple puzzle about crossing the seven bridges in the town of Königsberg was taken up by Euler and provided the foundation for an area of mathematics called graph theory. By walking the pattern of the seven bridges to work on this puzzle, students may begin to get an interest and feel for the problems of graph theory more generally.

Other instructors have done workshops on teaching history, drama, science, and classroom management in the garden. In the summer they offer courses for in-service teachers on how to meaningfully integrate a learning garden into their teaching.

Dr. Charlene Morton, an instructor at UBC, discussed how creating music relates to the concepts of sustainability and how these might be used in a classroom. Through activities like the "sound walk" (see the National Film Board of Canada's documentary Listen by Murray Schafer for more details), she takes students outside so that they can become more aware of sounds present in the environment through active listening and a contemplative practice, reflecting upon how we judge these sounds and how these relate to underlying social and environmental issues in the community. Dr. Morton elaborated:

What does integrating sustainability across the curriculum mean in the context of music education? To help teacher candidates understand...we begin by considering the commercial and true costs of the musical instruments in well-equipped university music classrooms. Following initial discussion...teacher candidates learn about the instruments' maintenance and replacement costs....For example, we find out how many new plastic recorders are purchased yearly and what this means in assessing how many are disposed of. This...usually leads to a discussion about the wide discrepancy among schools in what programming they can afford and the assumption that, for some, band and string programs are a right even though...[they]...may or may not be environmentally, culturally, or economically sustainable. The most salient question is "What's the most sustainable musical practice?" It doesn't take long...to surmise that singing is the best option...Nonetheless, more time is needed to accept singing as a sustainable alternative to playing with a variety of musical toys (acoustic/electronic) and surrender to the musical temptations of consumer marketing. I also explore sustainability through a PlayList assignment - students share personally-selected recorded music by posting it to an online forum. They comment about each others' reviews incorporating musical, social, and cultural aspects of their choices....However, it's too difficult for one assignment to foster a critical awareness about the economic, social, or environmental impact of our musical appetites.

\subsubsection{Graduate Teaching}

- Dr. Robert Vanwynsberghe explained recent planning initiatives focussed on sustainability.

[UBC recently examined] the principles and some of the possibilities of advancing sustainability programming in a way that brought together all of the departments. We met for a year...we have a Master's of Arts in sustainability and a Ph.D. program coming forward, a Master's of Education program lsee link http://pdce.educ.ubc.ca/med-in-curriculum-studies-ejs1-2/ for details], all in the faculty of education, all focussed on sustainability. We also have certificates, one in urban farming, another in teaching using gardens, and another in outdoor and environmental education...The other piece is a seminar series which argues for education for sustainability as a kind of field. It provides these kinds of rock-star people as resources who can come in and talk to others in the community and to university classes.

- Through the Peru Summer Institute "Ecology, Technologies and Ecololiteracies" (see http://www.students.ubc.ca/global/learning-abroad/group-study-programs/current-programs/peru/), indigeneity and sustainability are brought together. Two elective courses offer an international service-learning experience with Kichwa-Lamista communities in the High Amazon, these courses last four weeks and take place at the Sachamama Center for Biocultural Diversity in Lamas, Peru. 
- Dr. Vanwynsberghe describes an inter-institutional graduate-level course using a transdisciplinary approach:

We had four institutions, UBC, Simon Fraser University (SFU), Emily Carr, and British Colombia Institute for Technology (BCIT); we had students and instructors from all four places. We also had government employees who sat in the course. We ran it out of Science World one summer and out of another building downtown on another occasion. The focus was stakeholders' issues on the building of the Urban Trail. We brought together stakeholders and asked them what they saw as issues; they may raise an issue of riparian zones, or women's safety. Then a group of students would work together to address these issues and then brought them back to the stakeholders and in some cases implemented the solutions with them. Each summer we would pick up where we left off, we did that for three summers. Again this was all towards creating the possibility for inter-institutional courses for moving forward. At Emily Carr they're all artists and designers. They bring an aspect to your course that, until you experience it, you can't believe how valuable it is. For example, they would say, here's the stream, if we built this bridge, and they would build it with designer software, this is how it would protect the environment. SFU students are extremely strong and very community-oriented and BCIT are purely technical-oriented, we had this nice compliment.

\subsection{Simon Fraser University (SFU)}

SFU's faculty of education provides leadership in innovative pedagogies for teaching for and about ESD at both undergraduate and graduate levels. It arguably has offered the longest-standing environmental education summer institute in North America, now in its $44^{\text {th }}$ year of continuous course offerings. According to Dr. David Zandvliet, SFU's non-departmentalised structure at the faculty of education allows certain innovative collaborations in both teaching and research.

\subsubsection{Undergraduate Teaching}

The integration of ESD into the undergraduate program in the faculty of education at SFU is manifested in a number of ways:

- There is a Sustainability Education an Environment of Diversity (SEEDs) cohort in their faculty's undergraduate teacher education program.

- Elective courses with a focus on environmental education are offered. Dr. Zandvliet offers two environmental education courses which share a common process, approach and broad focus yet the contexts where the courses are offered and the specific content are unique one from the other. One takes place with the Haida Gwaii First Nation's community, and another is offered in metro-Vancouver. The latter was created 12 years ago to be more logistically accessible for students. To realize these courses, a "strategic partnership" has been created with the communities involved. Establishing courses like these involves a multi-year commitment as building these strong, long-standing, respectful relationships with communities takes time. Community members act as resource people and have input into the course, the teaching, and the assignments. These resource people, along with the use of local facilities, are considered as invaluable assets. The focus is on how the community works, students learn about the aspects that sustain a community (e.g., social programs, waste management systems). The course outline reflects a process of inquiry, a process of community engagement rather than a specific content. They are community-based and involve service and project-based learning. Experiential learning allows students to see a problem first hand. Zandvliet and Brown (2006) describe how in these courses, they directly link what the students are experiencing in the communities with their future teaching. By living a place-based pedagogy, it allows pre- and in-service teachers to interpret curriculum in a way that focusses learning within the context of a physical community. Place-based readings enrich students' understanding. For students in the sustainability cohort an "alternative" academic year, one that runs January to December, has provided a unique opportunity to take courses in the summer enabling student-teachers the possibility to integrate and experiment with their new ideas and understandings into their final practicum in the fall term. The theme of the metro-Vancouver course is "city as a living organism", it is open to pre-service and in-service teachers. Both the metro-Vancouver and Haida Gwaii courses incorporate a focus on environmental, social and economic components. The courses are a little different every year. For example, for 2012 the goal of the Haida Gwaii course was to design programs for the youth centre, especially for youth at risk. Successful completion of these environmental education courses contribute towards students earning a minor in environmental education.

At SFU, these courses are unique as they are twice the credit hours of a "normal course" ( 8 credit hours) usually 
lasting three weeks in the intensive residential format or over six weeks in the intersession format; they are ungraded. Zandvliet argues that they need to be this long otherwise they would not be logistically possible and would be less meaningful. Being ungraded seems important as the courses become "more about what students want to experiment with....more inquiry and open-ended" (Zandvliet). There are bureaucratic and systematic critiques that make the courses vulnerable highlighting the need for flexibility when accommodating these kinds of pedagogies. Fortunately, their long history at SFU and having a permanent faculty advocate helps protect them. (See Zandvliet \& Brown, 2006 , for more on the value of these programs and the relationship to the principles of environmental education).

\subsubsection{Graduate Teaching}

- The faculty of education offers a two-year master's program focusing on environmental education. Dr. Zandvliet describes the program: through the two-year program, students stay together in a cohort and take different courses part-time on alternate weekends and they do intensive summer-school courses. A summer course could include an international experience (e.g., a three-week field course in Australia). As part of the program, students do an action-research component (i.e., they study their own practice to become more critically-reflective); students propose teaching projects for their own milieu and then their advisor supports them in the process. The program also includes a project-based comprehensive exam.

\section{Discussion}

\subsection{Promising Practices Developing Competencies in ESD}

As mentioned in the introduction section, UNECE (2012) has identified core competences for ESD for educators. The 40 competences are divided into four clusters:

- learning to know (refers to understanding the challenges facing society both locally and globally and the potential role of educators and learners)

- learning to do (refers to developing practical skills and action competence in relation to education for sustainable development)

- learning to be (addresses the development of one's personal attributes and ability to act with greater autonomy, judgement and personal responsibility in relation to sustainable development)

- learning to live together (contributes to the development of partnerships and an appreciation of interdependence, pluralism, mutual understanding and peace)

In this section, we discuss the promise that we see in the practices and initiatives found in the four faculties of education to help develop these core competences for ESD for educators. In our discussion we will make reference to approximately half of the competences listed in UNECE (2012).

The promising initiatives described here reflect many of UNECE's (2012) recommendations to integrate ESD approaches across the curriculum in innovative ways and to provide ongoing professional development opportunities for teachers such as through critically-reflective practice. They support UNECE's (2012) recommendation that establishing partnerships between education and other actors ensures that the wider systems embrace ESD. They reflect a process of engaging people in the university and the community in a meaningful way in planning processes and the implementation of learning projects. These processes of inclusive collaboration within and outside institutions to problem-solve around locally-relevant real-world issues, potentially are helping create interdisciplinary opportunities that reflect ESD strategies.

For instance, Zandvliet's environmental education (SFU) courses and Vanwynsberghe's (UBC) inter-institutional graduate course are clear examples of inquiry-based, integrated, locally-relevant learning where students have an opportunity to act upon what they learn through looking at real-world problems — whether it be through implementing ideas with stakeholders or in their student practicum. The latter and York's joint master's program are examples of trying to break down the silos to become more integrated. These three cited examples, especially the former two enable, to a greater or lesser extent, the acquisition of competences towards an understanding of: systems thinking; the urgent need for change from unsustainable practices; the importance of problem setting, critical reflection, visioning and creative thinking in planning the future and effecting change; and how engagement in real-world issues enhances learning outcomes and practice (UNECE, 2012). These examples provide opportunities for learners to acquire competences that enable them to work in ways that: actively engage different groups across generations, cultures, places and disciplines; help learners clarify their own and others worldviews through dialogue; and recognize that alternative frameworks exist (UNECE, 2012). With respect to competences of learning to do, living these university experiences might enable future educators better to create opportunities for sharing ideas and 
experiences without prejudice and preconceptions; work with different perspectives on issues; and connect the learners to their local and global spheres of influence. In regards to learning to be, these promising practices potentially help the educator be someone who is inclusive of different disciplines, cultures and perspectives, including indigenous knowledge; is motivated to make a positive contribution to their local and global social and natural environment; and engages with learners in ways that build positive relationships.

The promising practices shared in this article vary in scale but clearly connect to their communities: for example, OISE/UT's work with local NGOs, UBC's speakers series or an activity as accessible as a sound walk. Larger-scale initiatives include UBC's learning garden, UBC's Peru summer institute or the aforementioned SFU's environmental education courses and UBC's inter-institutional graduate course. These are all embedded in the local and natural environment connecting local and global real-world issues, collaborating with local stakeholders in the learning process. With respect to the acquisition of key competences, through these activities educators could better understand, to a greater or lesser extent, their personal world view and cultural assumptions and seek to understand others; and the connection between sustainable futures and the ways we think, live and work. Many of these examples help pre- and in-service educators acquire competences that might enable them to work to: actively engage other groups across cultures; facilitate the emergence of new worldviews that address sustainable development; and to challenge unsustainable practices across educational systems. In regards to educators learning to do, these seven examples, as well as Dr. Dippo's teaching outdoors (York) use the natural, social and built environment, including their institutions, as a context and source of learning. To a greater or lesser extent, they all facilitate the evaluation of potential consequences of different decisions and actions. With respect to competences related to learning to be, these activities, generally, are inclusive of different disciplines, cultures and perspectives. These, and other examples like OISE/UT's mini-research grants or SFU's master's action-research project, provide opportunities for practitioners to be critically reflective; and some could inspire creativity and innovation. These examples reflect a sharing of responsibility with different stakeholders in a learning process.

\subsection{Challenges and Enablers of Reorienting Teacher Education Toward Sustainability}

\subsubsection{Challenges}

The case study suggests challenges to reorienting faculties of education programming toward sustainability. The first type of challenge is programmatic. The undergraduate programs of the four units of this case study are all one-year programs, which limits the introduction of a stand-alone ESD course to elective course. Only where ESD is integrated into already existing courses has it found its way into courses that reach all undergraduate students (OISE/UT; York). However, by 2014 Ontario teacher education programs (including those at York University and OISE/UT) will be moving to a two-year undergraduate program, which might open up opportunities for new courses with a stronger, more direct focus on ESD. Further, the current elective courses integrating ESD are vulnerable to disappear as they reflect current institutional priorities. At the moment, ESD is a priority area to some degree at the four universities. However, priority areas change. For instance, in spite of the strong focus on sustainability at OISE/UT, its ESD undergraduate elective was cancelled for the 2013-14 academic year. This potential challenge is further exacerbated by a turn over of deans and others in leadership positions.

The second type of challenge concerns logistical matters. Some of the innovative approaches to ESD in undergraduate programs require particular logistical accommodations in terms of time and place, which was, for instance, the case for SFU's environmental education courses. Logistical challenges also play a role when study participants expressed that working cross-disciplinary is challenging and time consuming. This challenge was articulated by many interviewees but particularly with respect to the community-based courses (e.g. SFU's environmental education) and when attempting to meaningfully integrate ESD throughout an undergraduate thematic-cohort's course work. These challenges align well with the larger challenges to the integration of ESD into universities identified, for instance, by Lidgren, Rodhe, and Huisingh (2006), and Stephens et al. (2008).

\subsubsection{Enablers}

Although challenges do exist to implementing ESD initiatives (see Hopkins \& McKeown, 2005), these initiatives show how some of these barriers are being overcome: by enabling interdisciplinary learning opportunities, by collaborating with a community of experts to tap local knowledge, by providing direction with a clear university-wide mandate to integrate ESD into university activities.

There are many factors that provided a fertile context, both at an institutional and a broader level, for these practices to occur. Beginning at an institutional level (which, depending on the context could mean faculty and/or university-level), in all of the case studies highlighted here, champions of ESD built upon their institutions' strengths. 
A successful approach was beginning by understanding and learning where people were coming from and what resources already existed at that particular institution. The work in recent years to broaden that focus to encompass a more comprehensive approach towards ESD built upon these strengths, whether it was by incorporating more environmental education and eco-justice or an incorporation of social justice and equity issues. The evolution of OISE/UT's Environmental and Sustainability Education Infusion Initiative provides a glimpse as to how this was done. Swayze et al. (2012) found, and this was confirmed by some participants in this study, that the UN decade on ESD contributed significantly in helping early adopters to create a legitimate space for ESD debate and action across their faculties. However, albeit that faculty and university integration of ESD initiatives is increasing, this study affirms Swayze et al.'s (2012) findings that ESD adoption is still primarily individual faculty-members' commitment rather than a faculty-wide response.

Like with most Canadian universities (Swayze et al., 2012), these case studies all have some sort of policy related to sustainable development. With respect to a vision or clear mandate for ESD, in all case-study contexts, some kind of inclusive process was facilitated to create a guiding vision or document for the work they are doing at a faculty and/or university level. At OISE/UT, for example, these include the creation of a Vision Statement for the Environmental and Sustainability Education Infusion Initiative; its Learner Document outlines capacities, including ones directly related to environmental and sustainability education, that they are trying to engender through their various faculty of education programs; and a forthcoming Guide to Environmental Education in Pre-Service Teacher Education created collaboratively via a provincial roundtable of environmental education. At UBC these guiding documents have included Transforming Sustainability Education at UBC: Desired Student Attributes and Pathways for Implementation (see USI Teaching and Learning Office and 2010 TLO Fellows, 2011) led by the University Sustainability Initiative Teaching and Learning Office, the Environmental Education Caucus Green Paper created by the Environmental Education Caucus/Sustainability Working Group, and a Faculty of Education Plan as described by Dr. Vanwynsberghe. This process of planning together has provided significant opportunities for people to get to know each other and to build community. It has also resulted in a pathway to move forward together. As mentioned previously, participatory decision-making is an important characteristic of ESD (McKeown, 2006; UNECE, 2012). Sinclair, Diduck, and Fitzpatrick (2008) stress the importance of inclusive planning processes as meaningful participation can result in participant empowerment and learning. Directly addressing challenges identified by Hopkins and McKeown (2005), having a clear mandate helps raise awareness and prioritize sustainability in the education community. Moreover, when there is a clear mandate, it gives legitimacy to ESD work and provides space where individuals can pressure and expect institutional resources for these initiatives.

A challenge identified by participants in this study when collaborating around ESD, which might be particularly significant when creating these aforementioned guiding documents, has been the search for appropriate language. This challenge was also identified by Stephens, Hernandez, Román, Graham, and Scholz (2008) in their findings. Most interviewees articulated the need to look critically at the language being used and the concepts that they in turn represent. Depending on the context, a language should be used that will enable collaboration and understanding and not create barriers. For example, at OISE/UT, they chose the expression "environmental and sustainability education" and at York the term "ESD" is commonly used.

Logistical supports at an institutional level are also important. These could include support for the overall coordination of ESD initiatives or enabling collaboration with national and international organizations. OISE/UT provides release time for an infusion lead in the faculty of education - release time and funding support are two particularly important enablers identified by Hopkins and McKeown (2005). UBC created a University Sustainability Initiative office to coordinate a fully-integrated university-wide approach to ESD. York University supports the broader national and international ESD work by providing office space to house Learning for a Sustainable Future and Dr. Chuck Hopkins' UNESCO Chair on Reorienting Teacher Education to Address Sustainability. Supportive institutional leadership as a central enabler for reorientation in faculties of education has also been identified in other studies (see, for instance, Falkenberg \& Babiuk, in press).

Faculties of education are grounded within a broader educational context. Interviewees identified outside enablers that have helped create a fertile environment for ESD initiatives at universities. Across Canada, much work has been done by provincial and territorial ministries of education, as well as other organizations, to build awareness and support programming and policy change consistent with ESD (see, for instance, Buckler \& MacDiarmid, 2013; Swayze et al., 2012). Findings showed that recent Ontario and BC provincial environmental education policies (i.e., Acting today, Shaping tomorrow in Ontario and Environmental Learning and Experience in BC) served as enablers for initiatives around ESD in faculties of education affirming Hopkins and McKeown's (2005) recommendation that ministries of education and faculties can mutually support each others' work. For example, Dr. Inwood (OISE/UT) 
cited how in 2007 the forthcoming Ontario environmental education policy helped create a legitimate entry-point to discuss the integration of ESD into their B.Ed. program. Many interviewees from UBC and SFU mentioned how helpful BC's ministry of education document, coupled with a general appreciation for sustainability in Vancouver, have been in terms of enabling the integration of ESD into their undergraduate and graduate programs.

\section{Conclusion}

Overall, as this case-study illustrates, preparing for competences in ESD involves meaningful and experiential learning in nature and with communities; it involves connecting to place and people. The importance of building partnerships was seen in the close collaboration with colleagues, students, and community organizations. Moreover, the initiatives studied highlight the importance of thinking outside the box to provide inter-disciplinary and inter-institutional learning opportunities that problem-solve around real-life issues with communities and the environment. Indigenous perspectives were suggested to greatly enrich our understanding and practice of ESD. Inclusive and participatory decision-making processes were important with respect to engaging people meaningfully, building a broader support base, and raising awareness. These various initiatives highlight possibilities for integrating into higher education discussions that explore values and attitudes towards sustainability and social justice. Strong administrative support has helped to support individual and collective work on reorienting teacher education toward sustainability.

This case study elucidates how faculties of education in four Canadian universities successfully integrate ESD into their teacher education programs through curriculum, pedagogical approaches, and ESD-related initiatives, and what challenges and enablers create the particular contexts for these initiatives. Others might adapt, and build upon, these initiatives according to their specific contexts. The initiatives reported upon in this study align well with Hopkins and McKeown's (2005) Guidelines and Recommendations for Reorienting Teacher Education to Address Sustainability. Future research should involve assessing the impact of these promising practices on the awareness and ESD competences of university students in faculties of education.

\section{Acknowledgements}

The authors are profoundly thankful to the research participants for their participation in this study. We thank Heather Creech and Carolee Buckler for their input and support. We also wish to acknowledge the financial support of the Social Sciences and Humanities Research Council of Canada. The reviewers made significant contributions to the improvement of this final manuscript for which we are very appreciative.

\section{References}

Alsop, S., Dippo, D., \& Zandvliet, D. B. (2007). Teacher education as or for social and ecological transformation: Place-based reflections on local and global participatory methods and collaborative practices. Journal of Education for Teaching, 33(2), 207-223. http://dx.doi.org/10.1080/02607470701259499

Blewitt, J., \& Cullingford, C. (Eds.). (2004). The sustainability curriculum: The challenge for higher education. London: Earthscan.

Brown, L. B. (1981). Building a sustainable society. New York: Norton.

Buckler, C., \& MacDiarmid, A. (2013). Education for sustainable development in Manitoba: A provincial-wide approach. In R. McKeown \& V. Nolet (Eds.), Schooling for sustainable development in Canada and the United States (pp. 95-108). Dordrecht, The Netherlands: Springer. http://dx.doi.org/10.1007/978-94-007-4273-4_7

Capra, F. (2002). The hidden connections: A science for sustainable living. New York: Anchor House.

Clayton, A. M. H., \& Radcliffe, N. J. (1996). Sustainability: A systems approach. Boulder, CO: Westview Press.

Coffey, A., \& Atkinson, P. (1996). Making sense of qualitative data: Complementary research strategies. Thousand Oaks, CA: Sage Publications.

Creswell, J. W. (2007). Qualitative inquiry \& research design: Choosing among five approaches (2 ${ }^{\text {nd }}$ ed.). Thousand Oaks, CA: Sage Publications.

Dippo, D. (2013). Preservice teaching and pedagogies of transformation. In R. McKeown \& V. Nolet (Eds.), Schooling for sustainable development in Canada and the United States (pp. 69-78). Dordrecht, The Netherlands: Springer. http://dx.doi.org/10.1007/978-94-007-4273-4_5

Down, L. (2006). Addressing the challenges of mainstreaming education for sustainable development in higher education. International Journal of Sustainability in Higher Education, 7(4), 390-399. http://dx.doi.org/10.1108/14676370610702190

The Earth Charter.

Published by Sciedu Press (n.d.).

[Online]
Available: 
http://www.earthcharterinaction.org/content/pages/Read-the-Charter.html

Environmental Education Caucus. (2011). Environmental Education Caucus green paper. [Online] Available: http://eecaucus.educ.ubc.ca/ee-caucus-green-paper-2/

Environmental \& Sustainability Education Infusion Initiative (n.d.). [Online] Available: www.oise.utoronto.ca/ite/UserFiles/File/ESE.pdf

Falkenberg, T., \& Babiuk, G. (in press). The status of education for sustainability in initial teacher education programs: A Canadian case study. International Journal of Sustainability in Higher Education.

Ferreira, J.-A., Ryan, L., \& Tilbury, D. (2007). Mainstreaming education for sustainable development in initial teacher education in Australia: A review of existing professional development models. Journal of Education for Teaching, 33(2), 225-239. http://dx.doi.org/10.1080/02607470701259515

Fien, J., \& Mclean, R. (2000). Teacher education for sustainability: Two teacher education projects from Asia and the Pacific. In K. A. Wheeler \& A. P. Bijur (Eds.), Education for a sustainable future: A paradigm for the $21^{\text {st }}$ century (pp. 91-111). New York: Kluwer Academic. http://dx.doi.org/10.1007/978-1-4615-4277-3_7

Firth, R., \& Winter, C. (2007). Constructing education for sustainable development: The secondary school geography curriculum and initial teacher training. Environmental Education Research, 13(5), 599-619. http://dx.doi.org/10.1080/13504620701659079

Gadotti, M. (2010). Reorienting education practices towards sustainability. Journal of Education for Sustainable Development, 4(2), 203-211. http://dx.doi.org/10.1177/097340821000400207

Greenwood, D. (2008). A critical pedagogy of place: From gridlock to parallax. Environmental Education Research, 14(3), 336-348. http://dx.doi.org/10.1080/13504620802190743

Gruenewald, D. (2003). The best of both worlds: A critical pedagogy of place. Educational Researcher, 32(4), 3-12. http://dx.doi.org/10.3102/0013189X032004003

Hopkins, C., Damlamian, J., \& López Ospina, G. (1996). Evolving towards education for sustainable development: An international perspective. Nature \& Resources, 32(3), 2-11.

Hopkins, C., International Network of Teacher Education Institutions, \&McKeown, R. (Eds.).(2007). Good practices in teacher education institutions, Paris: UNESCO.

Hopkins, C. A., \& McKeown, R. (2005). Guidelines and recommendations for reorienting teacher education to address sustainability. Paris: UNESCO (Section for Education for Sustainable Development). [Online] Available: http://unesdoc.unesco.org/images/0014/001433/143370e.pdf

Jucker, R. (2002). Our common illiteracy: Education as if the earth and people mattered. Frankfurt/Main: Peter Lang.

Lozano, R. (2006) Incorporation and institutionalization of SD into universities: Breaking through barriers to change. Journal of Cleaner Production, 14(9-11), 787-796. http://dx.doi.org/10.1016/j.jclepro.2005.12.010

Lidgren, A., Rodhe, H., \& Huisingh, D. (2006). A systemic approach to incorporate sustainability into university courses and curricula. Journal of Cleaner Production, 14(9-11), 797-809. http://dx.doi.org/10.1016/j.jclepro.2005.12.011

Mahruf, M., Shohel, C., \& Howes, J. (2011). Models of education for sustainable development and nonformal primary education in Bangladesh. Journal of Education for Sustainable Development, 5(1), 129-139. http://dx.doi.org/10.1177/097340821000500115

Maxwell, J. A. (1996). Qualitative research design: An interactive approach. Thousand Oaks, CA: Sage Publications.

McKeown, R. (with Hopkins, C. A., Rizzin, R, \& Chrystalbridge, M.) (2006). Education for sustainable development toolkit. Paris: UNESCO.

McKeown, R., \& Hopkins, C. (2007). International Network of Teacher Education Institutions: Past, present and future. Journal of Education for Teaching, 33(2), 149-155. http://dx.doi.org/10.1080/02607470701259408

Minguet, P. A., Martinez-Agut, M. P., Palacios, B., Piňero, A., \& Ull, M. A. (2011). Introducing sustainability into university curricula: An indicator and baseline survey of the views of university teachers at the University of Valencia. Environmental Education Research, 17(2), 145-166. http://dx.doi.org/10.1080/13504622.2010.502590

Mochizuki, Y., \& Fadeeva, Z. (2010). Competences for sustainable development and sustainability: Significance and challenges for ESD. International Journal of Sustainability in Higher Education, 11(4), 391-403. http://dx.doi.org/10.1108/14676371011077603 
Muhr, T. (1997). Nvivo. Berlin, Germany: Scientific Software Development.

Nolet, V. (2009). Preparing sustainability-literate teachers. Teachers College Record, 111(2), 409-442.

Nolet, V. (2013). Teacher education and ESD in the United States: The vision, challenges, and implementation. In R. McKeown \& V. Nolet (Eds.), Schooling for sustainable development in Canada and the United States (pp. 53-67). Dordrecht, The Netherlands: Springer. http://dx.doi.org/10.1007/978-94-007-4273-4_4

OISE/UT (2011). Initial teacher education, Bachelor of education/Diploma in Technological Education Consecutive Program, Master of Teaching Program and The University of Toronto Concurrent Program Learner Document. [Online] Available: www.oise.utoronto.ca/ite/UserFiles/File/Learner_Document.pdf

Paige, K., Lloyd, D., \& Chartres, M. (2008). Moving towards transdisciplinarity: An ecological sustainable focus for science and mathematics pre-service education in the primary/middle years. Asia-Pacific Journal of Teacher Education, 36(1), 19-33. http://dx.doi.org/10.1080/13598660701793350

Robertson, C. L., \& Krugly-Smolska, E. (1997). Gaps between advocated practice and teaching realities in environmental education. Environmental Education Research, 3(3), 311-326. doi:10.1080/1350462970030305

Scott, W., \& Gough, S. (2003). Sustainable development and learning: Framing the issues. London: RoutledgeFalmer. http://dx.doi.org/10.4324/9780203464625

Senge, P., Smith, B., Kruschwitz, N., Laur, J., \& Schley, S. (2008). The necessary revolution: How individual and organizations are working together to create a sustainable world. New York: Doubleday.

Sinclair, A. J., Diduck, A. P., \& Fitzpatrick, P., (2008). Conceptualizing learning for sustainability through environmental assessment: Critical reflections on 15 years of research. Environmental Impact Assessment Review, 28(7), 415-422. http://dx.doi.org/10.1016/j.eiar.2007.11.001

Sterling, S. (2001). Sustainable education: Re-visioning learning and change. Devon, UK: Green Books.

Stephens, J., Hernandez, M., Román, M., Graham, A., \& Scholz, R. (2008), Higher education as a change agent for sustainability in different cultures and contexts. International Journal of Sustainability in Higher Education, 9(3), 317-338. http://dx.doi.org/10.1108/14676370810885916

Stevenson, R. B. (2008). A critical pedagogy of place and the critical place(s) of pedagogy. Environmental Education Research, 14(3), 353-360. http://dx.doi.org/10.1080/13504620802190727

Summers, M., Childs, A., \& Corney, G. (2005). Education for sustainable development in initial teacher training: Issues for interdisciplinary collaboration. Environmental Education Research, 11(5), 623-647. http://dx.doi.org/10.1080/13504620500169841

Swayze, N., Creech, H., Buckler, C., \& Alfaro, J. (2012). Education for sustainable development in Canadian faculties of education. Toronto: Council of Ministers of Education, Canada. [Online] Available: http://www.cmec.ca/Publications/Lists/Publications/Attachments/279/ESD_Dean_reportEN.pdf

Tilbury, D. (2011). Education for sustainable development: An expert review of processes and learning. Paris: UNESCO.

United Nations Economic Commission for Europe. (2012). Learning for the future: Competences in education for sustainable development. Geneva, Switzerland: Author.

United Nations Educational, Scientific and Cultural Organization. (2010). Teaching and learning for a sustainable future: A multimedia teacher education program. Paris: Author. Retrieved from http://www.unesco.org/education/tlsf/

USI Teaching and Learning Office and 2010 TLO Fellows (2011). Transforming sustainability education at UBC: Desired student attributes and pathways for implementation. [Online] Available: http://sustain.ubc.ca/sites/sustain.ubc.ca/files/uploads/pdfs/Sustainability\%20Attributes_August\%202011_FINA L\%20\%282\%29.pdf

Wheeler, K. A., (2007). Learning for deep change. Journal of Education for Sustainable Development, 1(1), 45-50. http://dx.doi.org/10.1177/097340820700100110

World Commission on Environment and Development. (1987). Our common future. New York: Oxford University Press.

Yin, R. K. (2009). Case study research: Design and methods ( $4^{\text {th }}$ ed.). Thousand Oaks, CA: Sage Publications.

Zandvliet, D., \& Brown, D. (2006). Framing experience on Haida Gwaii: An ecological model for environmental education. Canadian Journal of Environmental Education, 11(1), 207-219. 